\title{
Novel Solid Phase Extraction Procedure for Some Trace Elements in Various Samples Prior to Their Determinations by FAAS
}

\author{
Şerife SAÇMACI, ${ }^{*}$ Şenol KARTAL, Mustafa SAÇMACI, ${ }^{\dagger}$ and Cengiz SOYKAN ${ }^{\dagger}$ \\ Erciyes University, Department of Chemistry, Faculty of Arts and Sciences, TR-38039, Kayseri, Turkey \\ ${ }^{*}$ E-mail: sacmaci@erciyes.edu.tr \\ ${ }^{\dagger}$ Bozok University, Department of Chemistry, Faculty of Arts and Sciences, 66200, Yozgat, Turkey \\ Received August 3, 2010, Accepted November 25, 2010
}

\begin{abstract}
A novel method that utilizes poly(5-methyl-2-thiozyl methacrylamide-co-2-acrylamido-2-methyl-1-propanesulfonic acid-co-divinylbenzene) [MTMAAm/AMPS/DVB] as a solid-phase extractant was developed for simultaneous preconcentration of trace $\mathrm{Cd}(\mathrm{II}), \mathrm{Co}(\mathrm{II}), \mathrm{Cr}(\mathrm{III}), \mathrm{Cu}(\mathrm{II}), \mathrm{Fe}(\mathrm{III}), \mathrm{Mn}(\mathrm{II}), \mathrm{Ni}(\mathrm{II}), \mathrm{Pb}(\mathrm{II})$, and $\mathrm{Zn}(\mathrm{II})$ prior to the measurement by flame atomic absorpiton spectrometry (FAAS). Experimental conditions for effective adsorption of the metal ions were optimized using column procedures. The optimum $\mathrm{pH}$ value for the simultaneously separation of the metal ions on the new adsorbent was 2.5. Effects of concentration and volume of elution solution, sample flow rate, sample volume and interfering ions on the recovery of the analytes were investigated. A high preconcentration factor, 100, and low relative standard deviation values, $\leq 1.5 \%(\mathrm{n}=10)$, were obtained. The detection limits $\left(\mu \mathrm{g} \mathrm{L}^{-1}\right)$ based on the $3 \mathrm{~s}$ criterion were 0.18 for $\mathrm{Cd}(\mathrm{II}), 0.11$ for $\mathrm{Co}(\mathrm{II}), 0.07$ for $\mathrm{Cr}$ (III), 0.12 for $\mathrm{Cu}(\mathrm{II}), 0.18$ for $\mathrm{Fe}(\mathrm{III}), 0.67$ for $\mathrm{Mn}$ (II), 0.13 for $\mathrm{Ni}$ (II), 0.06 for $\mathrm{Pb}(\mathrm{II})$, and 0.09 for $\mathrm{Zn}$ (II). The validation of the procedure was performed by the analysis of two certified reference materials. The presented method was applied to the determination of the analytes in various environmental samples with satisfactory results.
\end{abstract}

Key Words: Chelating resin, Separation, Preconcentration, Trace element, FAAS

\section{Introduction}

The determination of metal ions at trace level is very important in the context of environmental protection, food and agricultural chemistry, and high purity materials. ${ }^{1}$ The release of heavy metals into the environment is a potential threat to water and soil quality as well as to aquatic life and human health. Moreover, metal ions do not degrade biologically like organic pollutants, their presence in industrial effluents or drinking water is a public health problem due to their ingestion and therefore possible accumulation in living organisms. ${ }^{2,3}$ For the determination of trace elements in environmental samples, inductively coupled plasma-atomic emission spectrometry (ICP-AES), ${ }^{4,5}$ inductively coupled plasma-mass spectrometry (ICP-MS) ${ }^{6}$ and atomic absorption spectrometry (AAS) ${ }^{7,8}$ are the most widely used techniques for analyzing these harmful metal ions. They are usually insufficient due to matrix interferences and very low concentrations of metal ions. Therefore, a separation/preconcentration step is required. ${ }^{8}$

Solid phase extraction is an extraction method that uses a solid phase and a liquid phase to isolate one, or one type, of analyte from a solution. Also, this method had the advantages of being more sensitive, simple environment friendly, faster and sampler saving. It has known as a powerful tool for separation and preconcentration of various inorganic and also organic analytes. 8,9

Among the various seperation and preconcentration techniques proposed up to now, solid phase extraction using a chelate resin is one of the most practical ways to satisfy these requirements. ${ }^{10-12}$ Therefore, a variety of chelating resins have been studied from the viewpoint of the effective and/or selective adsorption of elements. ${ }^{3}$ Much attention has been drawn to the synthesis of chelating resins and to the investigation of their adsorption behavior for the selective and quantitative separation of specific metal ions from various matrices, because both their adsorption ability and adsorption selectivity are superior to those of ion exchangers in a trace and/or ultra trace concentration range. Chelating resins are typically characterised by functional groups containing $\mathrm{O}, \mathrm{N}, \mathrm{S}$ and $\mathrm{P}$ donor atoms which coordinate to different metal ions. ${ }^{13-15}$

Crosslinked copolymers containing 2-acrylamido-2-methyl1-propanesulfonic acid functional groups (AMPS) have a great potential for many applications as ion-exchange resin and gas separation membrane in the water purification industry, and for monitoring heavy metals in various environmental samples. Chelating resins are superior for selectivity in solid phase extraction and ion exchange due to their triple functions, i.e., ion exchange, chelate formation and physical adsorption. Chelating and/or ion exchange type adsorbents used in speciation studies have shown a preferential affinity for a single oxidation state of metal. The chelating resin adsorbents, which have large specific surface areas and high adsorption rates, are increasingly used in removal and preconcentration of toxic metal ions from aqueous solutions. The adsorption of heavy metal ion from aqueous solution to adsorbent is usually affected by the surface functional groups of the adsorbent. ${ }^{16}$

Poly(5-methyl-2-thiozylmethacrylamide-co-2-acrylamido2-methyl-1-propanesulfonic acid-co-divinylbenzene) (MTMAAm/AMPS/DVB) resin includes a thiazole cycle. Thiazole and its derivatives have biological significance, e.g., they are found in the vitamin B1 molecule and coenzyme cocarboxylase. ${ }^{17}$ Various thiazole derivatives have shown herbicidal, 
anti-inflamatory, anti-microbial, and/or anti-parasitic activity. ${ }^{18}$ Therefore, this resin seems to be a suitable candidate for further chemical modifications.

In this work, poly(5-methyl-2-thiozyl methacrylamide-co-2acrylamido-2-methyl-1-propanesulfonic acid-co-divinylbenzene) as a new chelating resin for the separation/preconcentration of the metal ions has been proposed. The analytical conditions for the quantitative recoveries of the analyte ions including $\mathrm{pH}$, amounts of the resin, sample volume, etc. were investigated. According to our literature knowledge, there is no any study for separation/preconcentration of the analytes by using this chelating resin. We here report the usefulness of the chelating resin to separate and concentrate the metal ions in environmental samples. The new adsorbent has been used for the separation and preconcentration of trace $\mathrm{Cd}(\mathrm{II}), \mathrm{Co}(\mathrm{II}), \mathrm{Cr}(\mathrm{III}), \mathrm{Cu}(\mathrm{II}), \mathrm{Fe}(\mathrm{III})$, $\mathrm{Mn}(\mathrm{II}), \mathrm{Ni}(\mathrm{II}), \mathrm{Pb}(\mathrm{II})$, and $\mathrm{Zn}(\mathrm{II})$ ions occurring in water, soil and food samples prior to their determinations by FAAS.

\section{Experimental}

Instrument. A PerkinElmer model AAnalyst 800 flame atomic absorption spectrometer (Norwalk, CT, USA) equipped with a deuterium background correction system and an airacetylene burner was used for the determination of all the metal ions. The operating conditions adjusted in the spectrometer were carried out according to the standard guidelines of the manufacturer. A Consort model $\mathrm{C} 533 \mathrm{pH}$ meter with a combined $\mathrm{pH}$ glass-electrode was employed for measuring $\mathrm{pH}$ values in the aqueous phase.

Reagents and Solutions. Distilled deionized water (DDW) was used throughout the experimental works. All the reagents used were of analytical grade. High purity reagents purchased from Merck (Darmstadt, Germany) were used for preparation of all the stock solutions. Standard stock solutions of $\mathrm{Cd}(\mathrm{II})$, $\mathrm{Co}(\mathrm{II}), \mathrm{Cr}(\mathrm{III}), \mathrm{Cu}(\mathrm{II}), \mathrm{Fe}(\mathrm{III}), \mathrm{Mn}(\mathrm{II}), \mathrm{Ni}(\mathrm{II}), \mathrm{Pb}(\mathrm{II})$, and $\mathrm{Zn}(\mathrm{II})$ $\left(1,000 \mathrm{mg} \mathrm{L}^{-1}\right)$ were prepared by dissolving their nitrate salts in distilled deionized water with the addition of $1 \mathrm{~mol} \mathrm{~L}^{-1} \mathrm{HNO}_{3}$ and further diluted daily prior to use. The calibration standards were not submitted to the separation-preconcentration procedure. All the plastic and glassware were cleaned by soaking in dilute $\mathrm{HNO}_{3}(1+1)$ and rinsed with distilled deionized water prior to use.

The chelating resin, MTMAAm/AMPS/DVB, was synthesized as reported in the literature. ${ }^{16}$ The synthesized polymer was washed successively with $1 \mathrm{~mol} \mathrm{~L}^{-1} \mathrm{HNO}_{3}, \mathrm{NaOH}$, ethyl alcohol and distilled deionized water. Then the chelating resin was dried in an oven at about $60{ }^{\circ} \mathrm{C}$. A glass mini column containing $0.5 \mathrm{~g}$ of the resin in water suspension has $10 \mathrm{~cm}$ length and $1.0 \mathrm{~cm}$ in diameter. The resin bed height in the column was approximately $1.0 \mathrm{~cm}$. A small amount of glass-wool was placed on the top of the resin to avoid disturbance during the sample passage. The mini column was washed thoroughly with distilled water and then pre-conditioned at the working $\mathrm{pH} 2.5$ using acetic acid/ sodium acetate buffer solution before passing the solutions containing the analyte ions.

Synthesis of the Chelating Resin. Firstly, 5-methyl-2-thiozyl methacrylamide (MTMAAm) monomer was synthesized. For doing this, to a well-stirred solution of 2-amino-5-methylthia-

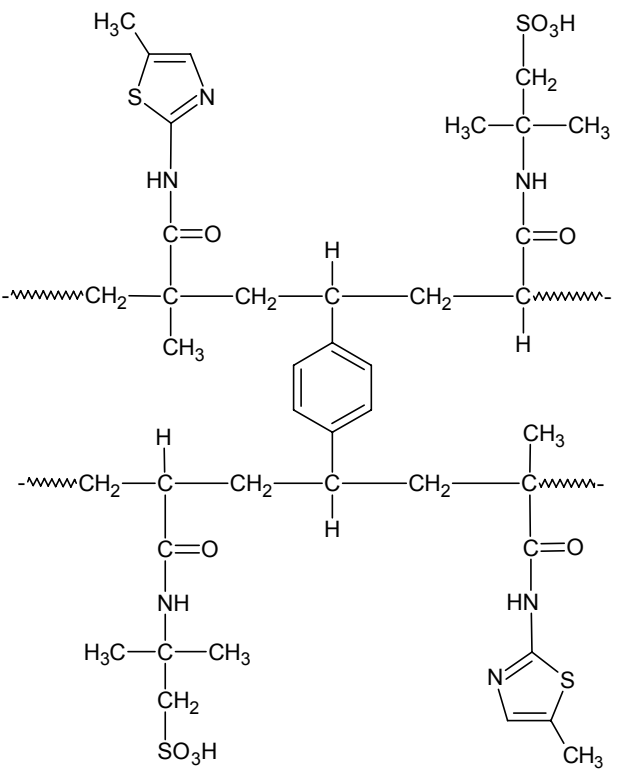

Figure 1. The structure of the polymer resin.

zole and triethylamine in dichloromethane, methacryloyl chloride was added dropwise under cooling conditions $\left(0-5{ }^{\circ} \mathrm{C}\right)$. After the complete addition of methacryloyl chloride, the reaction mixture was stirred for $12 \mathrm{~h}$ at room temperature, then filtered and evaporated with a rotavapor. A yellow product was obtained and recrystallized from ethanol as a yellow powder. The preparation of MTMAAm/AMPS/DVB resin was carried out with a radical initiator in dimethylformamide solution. To a polymerization flask, the two appropriate monomers MTMAAm and 2-acrylamido-2-methyl-1-propanesulfonic acid (AMPS), the crosslinking reagent divinylbenzene (DVB), and the initiator azobisisobutyronitrile (AIBN) were added. The system was kept under nitrogen for $3 \mathrm{~h}$ at $70^{\circ} \mathrm{C}$. Subsequently, the resin was filtered and washed with abundant diethylether and dried under vacuum at $50{ }^{\circ} \mathrm{C}$ until a constant weight was obtained. The conversion of the monomer to the polymer resin was determined gravimetrically (yield, $80 \%$ ). ${ }^{16}$ The structure of the polymeric resin is illustrated in Fig. 1.

General Procedure for Preconcentration. The preconcentration procedure was tested with the model solutions containing known amounts of the metal ions before application to real samples, and percentage recoveries were calculated. For doing this, $25 \mathrm{~mL}$ of the model solution containing the analytes was adjusted to the $\mathrm{pH} 2.5$ using $2 \mathrm{~mL}$ of acetic acid/sodium acetate buffer solution and the sample solution was loaded to the column. The flow of the sample solution through the mini column was gravitationally performed at a flow rate of $6.0 \mathrm{~mL} \mathrm{~min}^{-1}$. The flow rate of the sample solution was controlled by using the stopcock of the mini column. After being completed the passing of the sample solution, the column was washed with a small amount of distilled water. Then, the retained metal ions were eluted from the column by the aid of $10 \mathrm{~mL}$ of $2 \mathrm{~mol} \mathrm{~L}^{-1} \mathrm{HCl}$ at a flow rate of $6.0 \mathrm{~mL} \mathrm{~min}^{-1}$. The metal ion concentrations in the eluate solution were determined by the flame atomic absorption spectrometry (FAAS).

Analysis of Real Samples. A $0.1 \mathrm{~g}$ of soil sample was put into 
a $100 \mathrm{~mL}$ of beaker and a mixture of $6 \mathrm{~mL}$ of $\mathrm{HCl}(37 \%, \mathrm{w} / \mathrm{w})$ and $2 \mathrm{~mL}$ of $\mathrm{HNO}_{3}(65 \%$, w/w) was added and the digestion was performed on a hot plate adjusted to $200{ }^{\circ} \mathrm{C} .1 .0 \mathrm{~g}$ of each of black tea, cinnamon and dill samples, $0.5 \mathrm{~g}$ of INCT-TL-1 tea leaves certified reference material were digested with a mixture of $6 \mathrm{~mL}$ of concetrated $\mathrm{HNO}_{3}$ and $2 \mathrm{~mL}$ of $\mathrm{H}_{2} \mathrm{O}_{2}$ solutions. After the digestion, the suspension obtained from soil samples was filtered through a blue ribbon filter paper and completed to 50 $\mathrm{mL}$ with distilled deionized water. The resulting clear solutions from the plant samples were completed to $50 \mathrm{~mL}$ with distilled deionized water. Analyses for blank samples were carried out in the same way without sample. Then the preconcentrationseparation procedure given above was applied to the obtained solutions. After the preconcentration step, the final measurement volumes were completed to $5 \mathrm{~mL}$, and the solutions were measured by FAAS.

The proposed preconcentration procedure was also applied to SPS-WW2 Batch 108 certified reference material $(10 \mathrm{~mL})$, tap water, lake water, waste water and rain water samples (1000 $\mathrm{mL}$ ). The natural water samples were filtered through Millipore cellulose membrane filters $(0.45 \mu \mathrm{M}$ pore size, $47 \mathrm{~mm}$ diameter). The other processes for analyzing these water samples were the same just mentioned above.

\section{Results and Discussion}

Effect of pH. The $\mathrm{pH}$ is a very important factor for chelate formation in solid phase extraction processes for the purposes of separation and preconcentration. In order to find the optimum $\mathrm{pH}$, the effect of $\mathrm{pH}$ on the preconcentration of the metal ions using the chelating resin was investigated. For this purpose, $25 \mathrm{~mL}$ of model solution including $20 \mu \mathrm{g}$ of $\mathrm{Cr}$ (III), $\mathrm{Fe}$ (III) and $\mathrm{Pb}(\mathrm{II}), 10 \mu \mathrm{g}$ of $\mathrm{Mn}(\mathrm{II}), \mathrm{Co}(\mathrm{II}), \mathrm{Ni}(\mathrm{II})$ and $\mathrm{Cu}(\mathrm{II}), 5 \mu \mathrm{g}$ of $\mathrm{Cd}(\mathrm{II})$, and $2 \mu \mathrm{g}$ of $\mathrm{Zn}$ (II) was used in the $\mathrm{pH}$ range of $1-10$ by adjusting with buffer solutions. The retained ions were eluted by $10 \mathrm{~mL}$ of $2 \mathrm{~mol} \mathrm{~L}^{-1} \mathrm{HCl}$. The analyte ions in the eluate were determined by FAAS. The results are shown in Fig. 2 . The analyte ions were quantitatively recovered in the $\mathrm{pH}$ range of $1.5-4$. According to the results, the optimum $\mathrm{pH}$ was 2.5 for the purpose of multielement separation/preconcentration. So, the $\mathrm{pH} 2.5$ has been chosen as the separation/preconcentration acidity for the subsequent studies.

Effect of Type, Concentration and Volume of Eluent. For the elution of the trace metals adsorbed on the chelating resin, dilute acid solutions having different concentrations and volumes were investigated. For this reason, various elution solutions were used for desorption of the trace metals from the chelating resin. The results are given in Table 1. It was found that $10 \mathrm{~mL}$ of $2 \mathrm{~mol} \mathrm{~L}^{-1} \mathrm{HCl}$ was sufficient for complete elution of all the metal ions studied. Therefore, $10 \mathrm{~mL}$ of $2 \mathrm{~mol} \mathrm{~L}^{-1} \mathrm{HCl}$ solution was used as eluent in further experiments.

Effect of Flow Rate of Sample. The effect of the flow rate of sample solution was examined under the optimum conditions ( $\mathrm{pH} 2.5$, eluent: $10 \mathrm{~mL}$ of $2 \mathrm{~mol} \mathrm{~L}^{-1} \mathrm{HCl}$ ). The influences of the sample flow rate on the recoveries of the metal ions were investigated in the range of $1.0-10.0 \mathrm{~mL} \mathrm{~min}^{-1}$. The flow rates were adjusted with the aid of the stopcock of the column. The results are given in Fig. 3. For the flow rates higher than $6 \mathrm{~mL} \mathrm{~min}^{-1}$, the recovery of the metal ions were not quantitative, except for $\mathrm{Cr}$ (III) and $\mathrm{Co}(\mathrm{II})$ ions, and so a flow rate of $6 \mathrm{~mL} \mathrm{~min}^{-1}$ was chosen for the subsequent experiments for both sample and elution solutions.

Influences of the Amounts of the Chelating Resin. The effects of the amounts of the chelating resin on adsorption of the metals were investigated at the flow rates of $6 \mathrm{~mL} \mathrm{~min}^{-1}$ of sample and elution solutions. The results are given in Fig. 4. The recovery values increased with the increasing amounts of the chelating resin and reached to quantitative value (recovery about 100\%) for the amount of $0.5 \mathrm{~g}$ of the resin. The recovery of the metal ions decreased with increasing amounts of the resin beyond

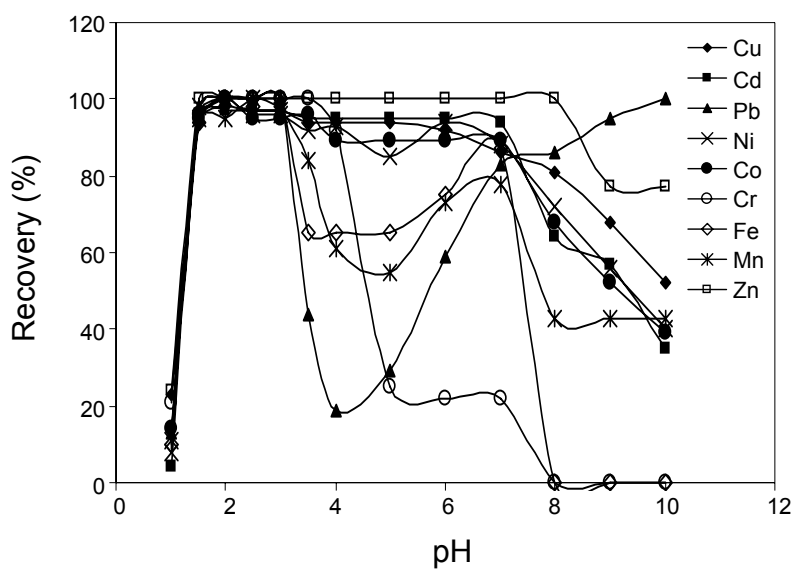

Figure 2. Effect of $\mathrm{pH}$ on the recovery of the analytes (sample volume: $25 \mathrm{~mL}$, chelating resin: $0.50 \mathrm{~g}$, eluent: $10 \mathrm{~mL}$ of $2 \mathrm{~mol} \mathrm{~L}^{-1} \mathrm{HCl}, \mathrm{n}=3$ ).

Table 1. Effect of volume and concentration of $\mathrm{HCl}$ and $\mathrm{HNO}_{3}$ solutions on the recovery of the analytes (sample volume: $25 \mathrm{~mL}, \mathrm{pH} 2.5, \mathrm{n}=3$ )

\begin{tabular}{|c|c|c|c|c|c|c|c|c|c|c|}
\hline \multirow{2}{*}{$\begin{array}{c}\text { Concentration and type of } \\
\text { eluent }\end{array}$} & \multirow{2}{*}{ Volume (mL) } & \multicolumn{9}{|c|}{ Recovery $(\%)^{a}$} \\
\hline & & $\mathrm{Cd}(\mathrm{II})$ & $\mathrm{Co}(\mathrm{II})$ & $\mathrm{Cr}(\mathrm{III})$ & $\mathrm{Cu}(\mathrm{II})$ & $\mathrm{Fe}(\mathrm{III})$ & $\mathrm{Mn}(\mathrm{II})$ & $\mathrm{Ni}(\mathrm{II})$ & $\mathrm{Pb}(\mathrm{II})$ & $\mathrm{Zn}(\mathrm{II})$ \\
\hline $3 \mathrm{~mol} \mathrm{~L}^{-1} \mathrm{HNO}_{3}$ & 25 & $95 \pm 1$ & $92 \pm 2$ & $100 \pm 1$ & $97 \pm 1$ & $100 \pm 1$ & $100 \pm 1$ & $96 \pm 1$ & $100 \pm 1$ & $91 \pm 2$ \\
\hline $3 \mathrm{~mol} \mathrm{~L}^{-1} \mathrm{HNO}_{3}$ & 10 & $95 \pm 1$ & $90 \pm 1$ & $100 \pm 2$ & $97 \pm 1$ & $100 \pm 2$ & $100 \pm 2$ & $95 \pm 1$ & $100 \pm 1$ & $90 \pm 3$ \\
\hline $2 \mathrm{~mol} \mathrm{~L}^{-1} \mathrm{HNO}_{3}$ & 10 & $91 \pm 2$ & $84 \pm 2$ & $100 \pm 2$ & $80 \pm 1$ & $88 \pm 2$ & $91 \pm 1$ & $88 \pm 2$ & $90 \pm 1$ & $100 \pm 2$ \\
\hline $2 \mathrm{~mol} \mathrm{~L}^{-1} \mathrm{HCl}$ & 10 & $98 \pm 1$ & $100 \pm 2$ & $100 \pm 1$ & $95 \pm 1$ & $100 \pm 1$ & $100 \pm 1$ & $99 \pm 1$ & $100 \pm 1$ & $100 \pm 2$ \\
\hline $1 \mathrm{~mol} \mathrm{~L}^{-1} \mathrm{HCl}$ & 10 & $96 \pm 1$ & $93 \pm 2$ & $100 \pm 3$ & $92 \pm 1$ & $100 \pm 3$ & $91 \pm 2$ & $89 \pm 1$ & $98 \pm 1$ & $95 \pm 3$ \\
\hline $2 \mathrm{~mol} \mathrm{~L}^{-1} \mathrm{HCl}$ & 5 & $76 \pm 2$ & $79 \pm 1$ & $91 \pm 1$ & $74 \pm 1$ & $100 \pm 1$ & $77 \pm 1$ & $77 \pm 3$ & $76 \pm 2$ & $57 \pm 1$ \\
\hline
\end{tabular}

${ }^{a}$ Average \pm standard deviation. 


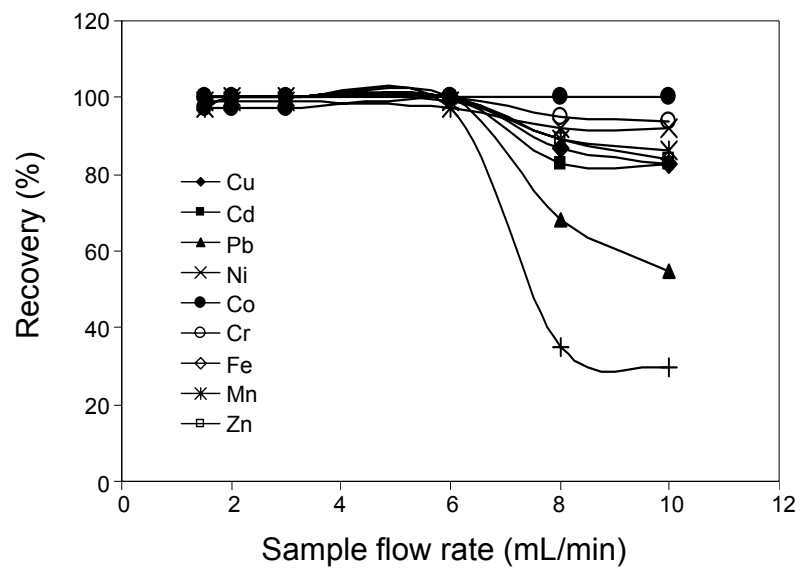

Figure 3. Effect of flow rate of sample solution on the recovery of the analytes (sample volume: $25 \mathrm{~mL}$, chelating resin: $0.5 \mathrm{~g}, \mathrm{pH} 2.5$, eluent: $10 \mathrm{~mL}$ of $2 \mathrm{~mol} \mathrm{~L}^{-1} \mathrm{HCl}, \mathrm{n}=3$ ).

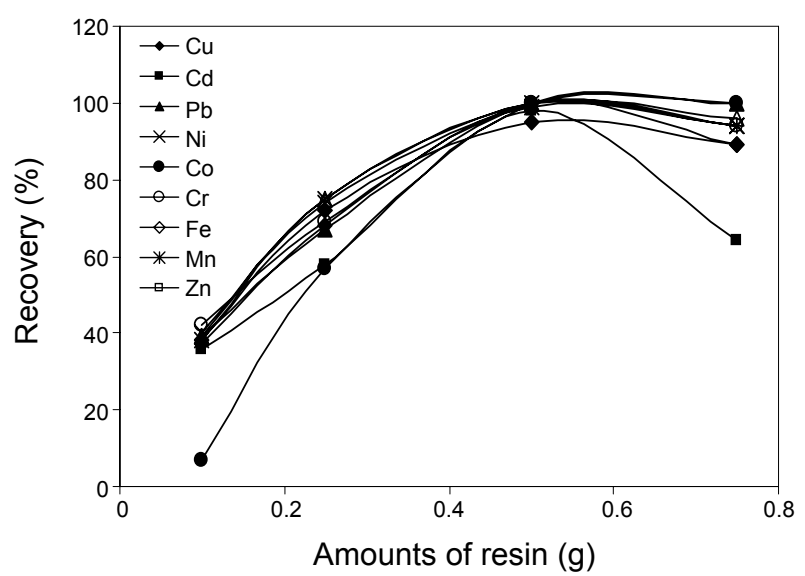

Figure 4. Influences of the amounts of the chelating resin (sample volume: $25 \mathrm{~mL}$, sample flow rate: $6 \mathrm{~mL} \mathrm{~min}^{-1}, \mathrm{pH} 2.5$, eluent: $10 \mathrm{~mL}$ of 2 $\mathrm{mol} \mathrm{L}{ }^{-1} \mathrm{HCl}, \mathrm{n}=3$ ).

$0.6 \mathrm{~g}$ due to the insufficient eluent volume. If the eluent volume was higher than $10 \mathrm{~mL}$, the recoveries were quantitative. In all subsequent studies, the glass column was filled with $0.5 \mathrm{~g}$ of the chelating resin.

Effect of Sample Volume. In order to deal with real samples, especially water samples, containing very low concentrations of the metal ions, the maximum applicable sample volume must be determined. For this purpose, $25-1000 \mathrm{~mL}$ volumes of the model solutions containing $2-20 \mu \mathrm{g}$ of the trace elements were passed through the column under the optimum conditions. The recovery values as a function of sample volume are shown in Fig. 5. The recoveries were quantitative and constant up to $1000 \mathrm{~mL}$ of the sample solution, except for $\mathrm{Cd}(\mathrm{II})$ and $\mathrm{Ni}(\mathrm{II})$, because they have been recovered quantitatively only up to $500 \mathrm{~mL}$ of the sample volume. The preconcentration factor was calculated as the ratio of the highest sample volume $(1000 \mathrm{~mL})$ to the eluent volume $(10 \mathrm{~mL})$ and found to be 100 for all the metal ions, except for $\mathrm{Cd}(\mathrm{II})$ and $\mathrm{Ni}(\mathrm{II})$ ions, which is 50 for them.

Effect of Matrix Ions. The effects of possible matrix ions

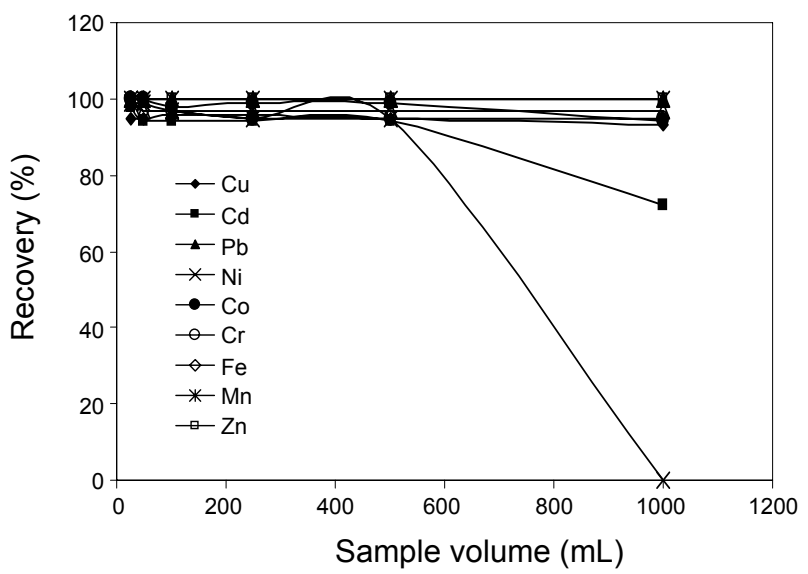

Figure 5. Effect of the sample volume on the recovery of the metal ions (resin amount: $0.5 \mathrm{~g}$, eluent: $10 \mathrm{~mL}$ of $2 \mathrm{~mol} \mathrm{~L}^{-1} \mathrm{HCl}, \mathrm{pH} 2.5$, sample

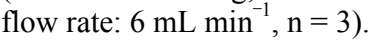

$\left(\mathrm{Na}^{+}, \mathrm{K}^{+}, \mathrm{Ca}^{2+}, \mathrm{Mg}^{2+}, \mathrm{Cl}^{-}, \mathrm{NO}_{3}{ }^{-}, \mathrm{SO}_{4}{ }^{2-}, \mathrm{PO}_{4}{ }^{3-}\right)$ present in environmental samples on the recoveries of the studied elements were also examined by adding the known concentration of each matrix ion to the model solution containing the studied trace elements. The results are summarized in Table 2. The tolerated amounts of each ion were the concentration values tested that caused less than 5\% alteration in the absorbance. Although some diverse ions have caused negative interfering effects on the recoveries of certain metal ions studied; i.e., $\mathrm{Na}^{+}, \mathrm{K}^{+}, \mathrm{SO}_{4}{ }^{2-}$ and $\mathrm{PO}_{4}{ }^{3-}$ on the recoveries of $\mathrm{Cd}(81-86 \%), \mathrm{Mg}^{2+}$ on the $\mathrm{Cr}$ and $\mathrm{Ni}$ $(90-92 \%), \mathrm{Na}^{+}, \mathrm{K}^{+}$and $\mathrm{Ca}^{2+}$ on the $\mathrm{Co}(90-92 \%), \mathrm{Cl}^{-}$on the $\mathrm{Fe}$ $(90 \%)$, and $\mathrm{Ca}^{2+}, \mathrm{Mg}^{2+}$ and $\mathrm{SO}_{4}{ }^{2-}$ on the $\mathrm{Mn}(80-89 \%)$. As can be seen from Table 2 , the ions normally present in natural samples did not interfere under the experimental conditions used (recoveries $\geq 95 \%$ ). These results indicate that the proposed separation/preconcentration method for the studied trace elements could be applied to various environmental samples.

Adsorption Capacity of the Resin. The adsorption capacity of the MTMAAm/AMPS/DVB resin for the analyte ions was studied using batch technique. A known amount of the chelating resin $(0.1 \mathrm{~g})$ was equilibrated with a known and excess amount of the metal ion solution $(10 \mathrm{mg}$ in $50 \mathrm{~mL}$ ) by shaking for $30 \mathrm{~min}$ at $\mathrm{pH} 2.5$. The mixture was then filtered off and the filtrate was diluted 20-100 fold. Concentrations of the metal ions in the filtrate were determined by FAAS. Adsorption capaties ( $\mathrm{mg} \mathrm{g}^{-1}$, $\mathrm{n}=3$ ) were found to be: $29.5 \pm 0.7$ for $\mathrm{Cd}(\mathrm{II}), 28.4 \pm 0.5$ for $\mathrm{Co}$ (II), $7.8 \pm 0.2$ for $\mathrm{Cr}$ (III), $4.3 \pm 0.1$ for $\mathrm{Cu}(\mathrm{II}), 41.2 \pm 1.2$ for $\mathrm{Fe}(\mathrm{III}), 18.6 \pm 1.1$ for $\mathrm{Mn}$ (II), $20.7 \pm 0.8$ for $\mathrm{Ni}(\mathrm{II}), 44.3 \pm 0.8$ for $\mathrm{Pb}(\mathrm{II})$, and $34.3 \pm 1.6$ for $\mathrm{Zn}$ (II).

Analytical Performance. In order to determine the detection limit (DL) of the proposed method, the $\mathrm{pH}$ of the blank solutions $\left(25 \mathrm{~mL}, \mathrm{n}=20\right.$ ) was adjusted to $\mathrm{pH} 2.5$ using $\mathrm{CH}_{3} \mathrm{COOH} / \mathrm{CH}_{3}-$ COONa buffer solution and then the preconcentration method was applied. The detection limits, calculated as the amount of analyte required to yield a net peak equal to three times the standard deviation of the blank solution, were found to be 0.18 for $\mathrm{Cd}(\mathrm{II}), 0.11$ for $\mathrm{Co}(\mathrm{II}), 0.07$ for $\mathrm{Cr}(\mathrm{III}), 0.12$ for $\mathrm{Cu}(\mathrm{II}), 0.18$ for $\mathrm{Fe}(\mathrm{III}), 0.67$ for $\mathrm{Mn}$ (II), 0.13 for $\mathrm{Ni}(\mathrm{II}), 0.06$ for $\mathrm{Pb}(\mathrm{II})$, and $0.09 \mu \mathrm{g} \mathrm{L}^{-1}$ for $\mathrm{Zn}(\mathrm{II})$. In the calculation of the DL of the method, 
Table 2. Effect of volume and concentration of $\mathrm{HCl}$ and $\mathrm{HNO}_{3}$ solutions on the recovery of the analytes (sample volume: $25 \mathrm{~mL}, \mathrm{pH} 2.5, \mathrm{n}=3$ )

\begin{tabular}{|c|c|c|c|c|c|c|c|c|c|c|}
\hline \multirow{2}{*}{ Ion } & \multirow{2}{*}{$\begin{array}{l}\text { Concentration } \\
\quad\left(\mathrm{mg} \mathrm{L}^{-1}\right)\end{array}$} & \multicolumn{9}{|c|}{ Recovery $(\%)^{a}$} \\
\hline & & $\mathrm{Cd}(\mathrm{II})$ & $\mathrm{Co}(\mathrm{II})$ & $\mathrm{Cr}(\mathrm{III})$ & $\mathrm{Cu}(\mathrm{II})$ & $\mathrm{Fe}(\mathrm{III})$ & $\mathrm{Mn}(\mathrm{II})$ & $\mathrm{Ni}(\mathrm{II})$ & $\mathrm{Pb}(\mathrm{II})$ & $\mathrm{Zn}(\mathrm{II})$ \\
\hline $\mathrm{Na}^{+}$ & 2500 & $84 \pm 1$ & $90 \pm 1$ & $95 \pm 1$ & $96 \pm 1$ & $100 \pm 1$ & $96 \pm 2$ & $100 \pm 1$ & $95 \pm 1$ & $98 \pm 2$ \\
\hline $\mathrm{K}^{+}$ & 4000 & $81 \pm 1$ & $90 \pm 1$ & $100 \pm 2$ & $98 \pm 1$ & $100 \pm 1$ & $94 \pm 2$ & $94 \pm 2$ & $96 \pm 1$ & $94 \pm 2$ \\
\hline $\mathrm{Ca}^{2+}$ & 800 & $94 \pm 1$ & $92 \pm 2$ & $100 \pm 2$ & $96 \pm 1$ & $94 \pm 1$ & $83 \pm 2$ & $100 \pm 1$ & $95 \pm 1$ & $94 \pm 1$ \\
\hline $\mathrm{Mg}^{2+}$ & 400 & $95 \pm 1$ & $94 \pm 1$ & $90 \pm 1$ & $100 \pm 2$ & $95 \pm 1$ & $80 \pm 2$ & $92 \pm 1$ & $95 \pm 1$ & $98 \pm 1$ \\
\hline $\mathrm{SO}_{4}{ }^{2-}$ & 1000 & $87 \pm 1$ & $96 \pm 1$ & $100 \pm 2$ & $96 \pm 1$ & $96 \pm 1$ & $89 \pm 1$ & $100 \pm 1$ & $90 \pm 1$ & $95 \pm 1$ \\
\hline $\mathrm{Cl}^{-}$ & 4500 & $95 \pm 1$ & $100 \pm 1$ & $95 \pm 2$ & $100 \pm 1$ & $90 \pm 2$ & $95 \pm 3$ & $100 \pm 1$ & $99 \pm 1$ & $95 \pm 2$ \\
\hline $\mathrm{NO}_{3}^{-}$ & 1000 & $96 \pm 1$ & $95 \pm 1$ & $96 \pm 1$ & $100 \pm 1$ & $97 \pm 1$ & $98 \pm 1$ & $96 \pm 1$ & $95 \pm 1$ & $98 \pm 2$ \\
\hline $\mathrm{PO}_{4}{ }^{3-}$ & 5000 & $86 \pm 1$ & $100 \pm 1$ & $99 \pm 1$ & $96 \pm 1$ & $98 \pm 1$ & $96 \pm 1$ & $95 \pm 1$ & $100 \pm 1$ & $99 \pm 3$ \\
\hline
\end{tabular}

${ }^{a}$ Average \pm standard deviation.

Table 3. The results of accuracy test for samples (sample volume: $250 \mathrm{~mL}$, final volume: $10 \mathrm{~mL}, \mathrm{n}=3$ )

\begin{tabular}{|c|c|c|c|c|c|c|}
\hline & \multirow{2}{*}{ Added $(\mu \mathrm{g})$} & \multicolumn{2}{|c|}{ Tap water } & \multirow{2}{*}{ Added $(\mu \mathrm{g})$} & \multicolumn{2}{|c|}{ Dill samples } \\
\hline & & Found $(\mu \mathrm{g})$ & Recovery (\%) & & Found $(\mu \mathrm{g})$ & Recovery (\%) \\
\hline \multirow[t]{3}{*}{$\mathrm{Cd}$} & - & - & - & - & $0.6 \pm 0.1$ & - \\
\hline & 15 & $14.3 \pm 0.2^{a}$ & 95 & 2.5 & $3.1 \pm 0.1$ & 100 \\
\hline & 30 & $29.2 \pm 0.6$ & 99 & 5.0 & $5.6 \pm 0.2$ & 100 \\
\hline \multirow[t]{3}{*}{ Co } & - & - & & - & - & - \\
\hline & 15 & $15.2 \pm 0.5$ & 101 & 5 & $4.9 \pm 0.3$ & 98 \\
\hline & 30 & $29.8 \pm 0.7$ & 97 & 10 & $9.8 \pm 0.7$ & 98 \\
\hline \multirow[t]{3}{*}{$\mathrm{Cr}$} & - & $3.6 \pm 0.5$ & - & - & - & - \\
\hline & 15 & $18.4 \pm 0.5$ & 99 & 5 & $4.9 \pm 0.6$ & 98 \\
\hline & 30 & $33.4 \pm 0.9$ & 99 & 10 & $9.9 \pm 0.5$ & 100 \\
\hline \multirow[t]{3}{*}{$\mathrm{Cu}$} & - & $33.3 \pm 0.3$ & & - & $6.1 \pm 0.3$ & - \\
\hline & 15 & $48.1 \pm 0.4$ & 99 & 15 & $20.9 \pm 0.4$ & 99 \\
\hline & 30 & $62.4 \pm 1.4$ & 97 & 30 & $35.8 \pm 0.6$ & 99 \\
\hline \multirow[t]{3}{*}{$\mathrm{Fe}$} & - & $29.3 \pm 1.4$ & - & - & $102 \pm 2$ & - \\
\hline & 15 & $44.1 \pm 1.1$ & 99 & 50 & $150 \pm 2$ & 96 \\
\hline & 30 & $59.4 \pm 1.4$ & 100 & 100 & $200 \pm 3$ & 98 \\
\hline \multirow[t]{3}{*}{$\mathrm{Mn}$} & - & - & - & - & $6.6 \pm 0.7$ & - \\
\hline & 15 & $14.6 \pm 0.5$ & 97 & 5 & $11.4 \pm 0.4$ & 96 \\
\hline & 30 & $28.9 \pm 1.3$ & 95 & 10 & $16.3 \pm 0.9$ & 97 \\
\hline \multirow[t]{3}{*}{$\mathrm{Ni}$} & & - & & - & $2.7 \pm 0.1$ & - \\
\hline & 15 & $14.8 \pm 0.4$ & 99 & 2.5 & $5.1 \pm 0.2$ & 96 \\
\hline & 30 & $29.7 \pm 0.6$ & 99 & 5.0 & $7.6 \pm 0.5$ & 98 \\
\hline \multirow[t]{3}{*}{$\mathrm{Pb}$} & - & - & - & - & - & - \\
\hline & 15 & $14.9 \pm 0.1$ & 99 & 5 & $5.1 \pm 0.2$ & 102 \\
\hline & 30 & $29.8 \pm 1.1$ & 99 & 10 & $9.8 \pm 0.4$ & 98 \\
\hline \multirow[t]{3}{*}{$\mathrm{Zn}$} & - & $57.0 \pm 1.6$ & - & - & $3.1 \pm 0.1$ & - \\
\hline & 25 & $82.6 \pm 1.8$ & 102 & 2.5 & $5.5 \pm 0.4$ & 96 \\
\hline & 50 & $108 \pm 2$ & 102 & 5.0 & $7.9 \pm 0.9$ & 96 \\
\hline
\end{tabular}

${ }^{a}$ Average \pm standard deviation.

the 100 fold preconcentration factor was taken into consideration. For the metal ions studied, regression coefficients $\left(\mathrm{R}^{2}\right)$ of the calibration curves were between 0.9990 and 0.9996 . The precision of the method under the optimum conditions was determined by performing successive 10 retention and elution cycles followed by FAAS. The relative standard deviations for the metals studied were lower than $2 \%$.

Accuracy and Application of the Method. In order to investi- gate the accuracy of the proposed procedure, the first work made was the recovery study. For this reason, the known amounts of the analyte ions were added to tap water and aqueous digests of dill samples and then the proposed method has been applied. The results are shown in Table 3. A good agreement was obtained between the added and the measured amounts of the metals. The recovery values calculated were always higher than $95 \%$, thus confirming the accuracy of the proposed proce- 
Table 4. The levels of trace elements in the certified reference materials after the application of the presented procedure

\begin{tabular}{|c|c|c|c|c|c|c|c|c|c|}
\hline & $\mathrm{Cd}(\mathrm{II})$ & $\mathrm{Co}(\mathrm{II})$ & $\mathrm{Cr}(\mathrm{III})$ & $\mathrm{Cu}(\mathrm{II})$ & $\mathrm{Fe}(\mathrm{III})$ & $\mathrm{Mn}(\mathrm{II})$ & $\mathrm{Ni}(\mathrm{II})$ & $\mathrm{Pb}(\mathrm{II})$ & $\mathrm{Zn}(\mathrm{II})$ \\
\hline \multicolumn{10}{|l|}{ SPS-WW2 Batch 108} \\
\hline Certified value $\left(\mu \mathrm{g} \mathrm{L}^{-1}\right)$ & $100.0 \pm 0.5$ & $300 \pm 2$ & $1000 \pm 5$ & $2000 \pm 10$ & $5000 \pm 25$ & $2000 \pm 10$ & $5000 \pm 25$ & $500 \pm 3$ & $3000 \pm 15$ \\
\hline Found $\left(\mu \mathrm{g} \mathrm{L}^{-1}\right)$ & $102 \pm 2^{a}$ & $304 \pm 4$ & $997 \pm 11$ & $1890 \pm 12$ & $5006 \pm 19$ & $1891 \pm 14$ & $4886 \pm 13$ & $497 \pm 8$ & $3015 \pm 11$ \\
\hline Recovery (\%) & 102 & 101 & 100 & 95 & 100 & 95 & 98 & 99 & 101 \\
\hline \multicolumn{10}{|l|}{ INCT-TL-1 tea leaves } \\
\hline Certified value $\left(\mu \mathrm{g} \mathrm{L}^{-1}\right)$ & $30.2 \pm 4.0$ & $387 \pm 42$ & $1.91 \pm 0.22$ & $20.4 \pm 1.5$ & 432 & $0.16 \pm 0.01$ & $6.12 \pm 0.52$ & $1.78 \pm 0.24$ & $34.7 \pm 2.7$ \\
\hline Found $\left(\mu \mathrm{g} \mathrm{L}^{-1}\right)$ & $29.8 \pm 1.3$ & $385 \pm 3$ & $1.88 \pm 0.20$ & $19.8 \pm 1.1$ & $435 \pm 4$ & $0.15 \pm 0.01$ & $6.00 \pm 0.40$ & $1.73 \pm 0.20$ & $34.1 \pm 1.1$ \\
\hline Recovery (\%) & 99 & 100 & 98 & 97 & 101 & 96 & 98 & 97 & 98 \\
\hline
\end{tabular}

${ }^{a}$ At $95 \%$ confidence level (mean $\left.\pm t \cdot s / \sqrt{ } \mathrm{n}\right)$.

Table 5. The application of the presented method to the real samples for their heavy metal contents $(n=3)$

\begin{tabular}{|c|c|c|c|c|c|c|c|c|c|}
\hline Metal ions & \multirow{2}{*}{$\mathrm{Cd}(\mathrm{II})$} & \multirow{2}{*}{$\mathrm{Co}(\mathrm{II})$} & \multirow{2}{*}{$\mathrm{Cr}(\mathrm{III})$} & \multirow{2}{*}{$\mathrm{Cu}(\mathrm{II})$} & \multirow{2}{*}{$\mathrm{Fe}(\mathrm{III})$} & \multirow{2}{*}{$\mathrm{Mn}(\mathrm{II})$} & \multirow{2}{*}{$\mathrm{Ni}(\mathrm{II})$} & \multirow{2}{*}{$\mathrm{Pb}(\mathrm{II})$} & \multirow{2}{*}{$\mathrm{Zn}(\mathrm{II})$} \\
\hline Water samples $\left(\mu \mathrm{g} \mathrm{L}^{-1}\right)$ & & & & & & & & & \\
\hline Tap water & - & - & $3.6 \pm 0.5^{a}$ & $33.3 \pm 0.3$ & $29.3 \pm 1.4$ & $-{ }^{b}$ & - & $0.13 \pm 0.06$ & $57.0 \pm 1.6$ \\
\hline Lake water & $1.6 \pm 0.4$ & - & $5.6 \pm 0.9$ & $4.8 \pm 0.4$ & $30.1 \pm 1.5$ & - & - & $6.4 \pm 0.9$ & $9.8 \pm 0.9$ \\
\hline Waste water & $2.1 \pm 0.8$ & $3.4 \pm 0.4$ & $19.0 \pm 1.8$ & $32.8 \pm 1.2$ & $88.4 \pm 1.9$ & $27.3 \pm 1.4$ & $15.1 \pm 1.3$ & $6.4 \pm 0.8$ & $26.3 \pm 1.1$ \\
\hline Rain water & - & - & - & $27.2 \pm 0.6$ & $195 \pm 2$ & $13.8 \pm 1.1$ & $10.2 \pm 1.1$ & - & $11.4 \pm 0.9$ \\
\hline \multicolumn{10}{|l|}{ Solid samples $\left(\mu \mathrm{g} \mathrm{g}^{-1}\right)$} \\
\hline Soil & $5.8 \pm 0.1$ & $0.5 \pm 0.1$ & $2.0 \pm 0.4$ & $3.5 \pm 0.5$ & $595 \pm 2$ & $7.5 \pm 0.9$ & $1.9 \pm 0.3$ & $6.3 \pm 0.8$ & $0.50 \pm 0.03$ \\
\hline Black tea & - & $0.3 \pm 0.1$ & - & $12.7 \pm 0.5$ & $9.0 \pm 1.1$ & $25.4 \pm 1.0$ & $4.6 \pm 0.2$ & $0.9 \pm 0.1$ & $1.7 \pm 0.1$ \\
\hline Dill & $0.58 \pm 0.1$ & - & - & $6.1 \pm 0.3$ & $102 \pm 2$ & $6.6 \pm 0.7$ & $2.7 \pm 0.1$ & - & $3.1 \pm 0.1$ \\
\hline Cinnamon & - & - & - & - & $6.7 \pm 0.6$ & $14.4 \pm 0.9$ & - & - & $3.5 \pm 0.8$ \\
\hline
\end{tabular}

${ }^{a}$ At $95 \%$ confidence level (mean $\left.\pm \mathrm{t} \cdot \mathrm{s} / \sqrt{ } \mathrm{n}\right) .{ }^{b}$ Below detection limit.

Table 6. Comparative data from some recent studies on preconcentration-separation of heavy metal ions

\begin{tabular}{|c|c|c|c|c|c|c|c|c|}
\hline Method & Analytes & System & Eluent & $\operatorname{DL}\left(\mu \mathrm{g} \mathrm{L}^{-1}\right)$ & $\operatorname{RSD}^{a}(\%)$ & $\mathrm{PF}^{b}$ & $\mathrm{pH}$ & Reference \\
\hline SPE & $\mathrm{Cd}, \mathrm{Co}, \mathrm{Cr}, \mathrm{Cu}, \mathrm{Fe}, \mathrm{Mn}, \mathrm{Ni}, \mathrm{Pb}, \mathrm{Zn}$ & FAAS & $2.0 \mathrm{~mol} \mathrm{~L}^{-1} \mathrm{HCl}$ & $0.06-0.67$ & $\leq 1.5$ & 100 & 2.5 & This work \\
\hline SPE & $\mathrm{Cd}, \mathrm{Co}, \mathrm{Cu}, \mathrm{Fe}, \mathrm{Mn}, \mathrm{Mo}, \mathrm{Ni}, \mathrm{Pb}, \mathrm{V}, \mathrm{Zn}$ & ICP-AES & $2.0 \mathrm{~mol} \mathrm{~L}^{-1} \mathrm{HNO}_{3}$ & $0.003-0.28$ & - & 50 & 5.5 & [3] \\
\hline SPE & $\mathrm{Cd}, \mathrm{Co}, \mathrm{Cu}, \mathrm{Mn}, \mathrm{Ni}, \mathrm{Pb}$ & FAAS & $1.0 \mathrm{~mol} \mathrm{~L}^{-1} \mathrm{HNO}_{3}$ & $0.08-0.26$ & $1.9-5.1$ & 100 & 8.0 & {$[8]$} \\
\hline SPE & $\mathrm{Cd}, \mathrm{Co}, \mathrm{Cu}, \mathrm{Pb}, \mathrm{Zn}$ & FAAS & $0.1 \mathrm{~mol} \mathrm{~L}^{-1} \mathrm{HCl}$ & $1.95-9.50$ & 2.98 & 17 & 6.7 & [19] \\
\hline SPE & $\mathrm{Cd}, \mathrm{Co}, \mathrm{Cu}, \mathrm{Fe}, \mathrm{Mn}, \mathrm{Ni}, \mathrm{Pb}, \mathrm{Zn}$ & FAAS & $\begin{array}{l}2.0 \mathrm{~mol} \mathrm{~L}^{-1} \mathrm{HCl}-1.5 \\
\mathrm{~mol} \mathrm{~L}^{-1} \mathrm{HNO}_{3}\end{array}$ & $0.3-13.9$ & $1.01-2.58$ & $100-300$ & $3.5-7.0$ & {$[20]$} \\
\hline SPE & $\mathrm{Cu}, \mathrm{Fe}, \mathrm{Zn}$ & FAAS & $4.0 \mathrm{~mol} \mathrm{~L}^{-1} \mathrm{HNO}_{3}$ & $0.95-1.0$ & $<4$ & 90 & 6.0 & {$[21]$} \\
\hline
\end{tabular}

${ }^{a}$ Relative standard deviation. ${ }^{b}$ Preconcentration factor.

dure and its independence from the matrix effects. These results confirm the validity of the proposed separation/preconcentration method.

To validate the accuracy of the solid phase extraction procedure, the second work made was to analyze the certified reference materials, SPS-WW2 Batch 108 Wastewater level 2 and INCT-TL-1 Tea leaves. The proposed method was applied to these two certified reference materials for the determination of the metal ions. The results are given in Table 4 . The observed values of the analytes in the certified reference materials were in good agreement with their certified values.

The method was also extended for the separation and preconcentration of the trace elements in tap water, waste water, lake water and rain water samples. The final measurement volume was $5 \mathrm{~mL}$ for all the samples. The results are shown in Table 5. The observed values of the analytes were in good agreement with those given in the literature for the real samples.

Comparison with Other Analytical Techniques. The comparison of the obtained results with those given in the literature is shown in Table 6 . The main novelty of this work is the firstly use of the MTMAAm/AMPS/DVB resin for the separation/preconcentration purpose by applying the solid phase extraction. The other advantages obtained with the proposed method can be explained in the following by sequence of importance: (a) low detection limits, (b) lower RSD\% values than those of the other methods, (c) the acidic working medium ( $\mathrm{pH} 2.5)$ and 
good tolerance limits towards many interfering ions, (d) the accuracy of the method are satisfactory, (e) the simultaneous nature of the determination, (f) the simplicity, accuracy, and easily applicability of the method, $(\mathrm{g})$ the easy elution of the analytes with only $10 \mathrm{~mL}$ of $2 \mathrm{~mol} \mathrm{~L}^{-1} \mathrm{HCl}$, (h) a high preconcentration factor, 100 , and (i) the resin has high recycle numbers.

\section{Conclusion}

This newly designed chelating resin can be successfully employed for the separation, preconctration and determination of Cd(II), Co(II), Cr(III), Cu(II), Fe(III), Mn(II), Ni(II), Pb(II), and $\mathrm{Zn}$ (II) ions in soil, food and various water samples by FAAS. The MTMAAm/AMPS/DVB material is an effective chelating resin and offers a useful multi-element preconcentration technique for applying to various environmental samples, such as lake water, waste water and solid samples with acceptable accuracy and precision. The high stability of the resin permitted hundreds of adsorption-elution cycles along the studies without any significant decrease in the recoveries. The validation of the developed method was successfully performed by analyzing the certified reference materials. Also the trace element contents were determined in natural waters, soil and food samples.

Acknowledgments. The authors are grateful for the financial support of the Unit of the Scientific Research Projects of Erciyes University with Project Contract No EÜBAP-FBA-07-34.

\section{References}

1. Minczewski, J.; Chwastowska, J.; Dybczynski, R. Separation and
Preconcentration Method in Inorganic Trace Analysis; Ellis Horwood/Halsted Press: Chichester, 1982; p 26.

2. Tu, Z.; He, Q.; Chang, X.; Hu, Z.; Gao, R.; Zhang, L.; Li, Z. Anal. Chim. Acta 2009, 649, 252.

3. Kagaya, S.; Maeba, E.; Inoue, Y.; Kamichatani, W.; Kajiwara, T.; Yanai, H.; Saito, M.; Tohda, K. Talanta 2009, 79, 146.

4. Boevski, I.; Daskalova, U. N.; Havezov, I. Spectrochim. Acta B 2000, 55, 1643.

5. Atanassova, D.; Stefanova, V.; Russeva, E. Talanta 1998, 47, 1237.

6. Nicolai, M.; Rosin, C.; Tousset, N.; Nicolai, Y. Talanta 1999, 50, 433.

7. Tarleya, C. R. T.; Santosa, V. S.; Baetaa, B. E. L.; Pereirab, A. C.; Kubota, L. T. J. Hazard. Mater. 2009, 169, 256.

8. Duran, C.; Gündoğdu, A.; Bulut, V. N.; Soylak, M.; Elçi, L.; Şentürk, H. B.; Tüfekçi, M. J. Hazard. Mater. 2007, 146, 347.

9. Rao, T. P.; Daniel, S.; Gladis, J. M. Trends Anal. Chem. 2004, 23, 28.

10. Camel, V. Spectrochim. Acta B 2003, 58, 1177.

11. Garg, B. S.; Sharma, R. K.; Bhojak, N.; Mittal, S. Microchem J. 1999, 61, 94.

12. Kantipuly, C.; Atragadda, S. K.; Chow, A.; Gesser, H. D. Talanta 1990, 37, 491.

13. Sharma, R. K.; Pant, P. J. Hazard. Mater. 2009, 163, 295.

14. Mashhadizadeh, M. H.; Pesteh, M.; Talakesh, M.; Sheikhshoaie, I.; Ardakani, M. M.; Karimi, M. A. Spectrochim. Acta B 2008, 63, 885 .

15. Zougagh, M.; Pavón, J. M. C.; Torres, A. G. Anal. Bioanal. Chem. 2005, 381, 1103 .

16. Saçmacı, Ş.; Saçmacı, M.; Soykan, C.; Kartal, Ş. J. Macromol. Sci. $A$ 2010, 47, 552.

17. Azab, M. M. J. Polym. Res. 2005, 12, 9.

18. Stieber, F.; Mazitschek, R.; Soric, N.; Giannis, A; Waldmann, H. Angew. Chem. Int. Ed. 2002, 41, 4757.

19. Alan, M.; Kara, D.; Fisher, A. Sep. Sci. Technol. 2007, $42,879$.

20. Venkatesh, G.; Jain, A.K.; Singh, A. K. Microchim. Acta 2005, 149, 213.

21. Ghaedi, M.; Niknam, K.; Shokrollahi, A.; Niknam, E.; Ghaedi, H.; Soylak, M. J. Hazard. Mater. 2008, 158, 131. 